Jurnal Ilmu Sosial dan Pendidikan (JISIP)

Vol. 5 No. 3 Juli 2021

Terakreditasi Peringkat 5 (No. SK: 85/M/KPT/2020)

e-ISSN : 2656-6753, p-ISSN: 2598-9944

DOI: 10.36312/jisip.v5i3.2190/http://ejournal.mandalanursa.org/index.php/JISIP/index

\title{
The Urgency Of Ratifying The Elimination Of Sexual Violence Draft Bill In The Perspective Of Criminal Law
}

\author{
Audaraziq Ismail ${ }^{1}$, Eva Achjani Zulfa ${ }^{2}$, Lulu Yulianti ${ }^{3}$, Matius Evan Anggara ${ }^{4}$ \\ ${ }^{1234}$ Fakultas Hukum Universitas Indonesia \\ Email: audaraziqismail37@gmail.com
}

\begin{tabular}{l}
\hline \hline Article Info \\
Article history: \\
Article Accepted: 09 July 2021 \\
Publication : 16 July 2021 \\
\end{tabular}

Keywords:

Sexual Violence, Urgency, The Elmination of Sexual Violence Draft Bill

\begin{tabular}{l}
\hline Article Info \\
\hline Article history: \\
Article Accepted: 09 July 2021 \\
Publication : 16 July 2021
\end{tabular}

\section{Kata Kunci:}

Kekerasan Seksual, Urgensi, RUU PKS

\section{Corresponding Author:}

\section{Audaraziq Ismail}

Fakultas Hukum Universitas Indonesia e-mail: audaraziqismail37@gmail.com

\begin{abstract}
Regulations on sexual violence or violence are scattered in several regulations in Indonesia. However, along with the rapid and massive technological development, new form of criminal offenses related to sexual violence have emerged which have not been accommodated in the statutory regulations. Too many regulations related to sexual violence also create new problems, specifically overcriminalization, overlapping, and the lack of coordination and systematic fulfillment of the protection for the rights of victims of violence by authorized institutions. These problems are the fundamental why the elimination of sexual violence draft bill should be ratified immediately. Based on the reasons above, the elimination of sexual violence draft bill is interesting to analyze. This research was conducted with a statutory approach and an analytical approach using relevant legal concepts and theories. Criminal offenses related to sexual violence are regulated in several regulations, the Criminal Code, the PKDRT Law, the TPPO Law, the ITE Law, the Child Protection Law and the Pornography Law. However the law that exist are not comprehensive yet for the expansion of criminal offenses for violence and fulfillment of the rights of victims who are not the subject according to the law, as well as the issue of overregulation becomes the urgency why elimination of sexual violence draft bill should be ratified immediately.

Abstrak
Pengaturan tentang Kejahatan atau kekerasan seksual di Indonesia tersebar
diberbagai peraturan perundang-undangan di Indonesia. Namun dengan seiring
perkembangan terknologi yang cepat dan massif, maka muncul delik-delik pidana
baru terkait kekerasan seksual yang belum terakomodir dalam peraturan perundang-
undangan. Terlalu banyak peraturan yang mengatur delik terkait kekerasan seksual
juga menimbulkan permasalahan baru yakni overcriminalization, overlapping, dan
kurang terkoordinasi dan tersistematisnya pemenuhan perlindungan hak-hak korban
kekerasan seksual oleh Lembaga-lembaga yang berwenang. Permasalahan ini
menjadikan urgensi pengesahan RUU PKS menjadi menarik dari perspektif hukum
pidana. Untuk itu penelitian ini dilakukan dengan pendekatan undang-undang dan
pendekatan analisis menggunakan konsep dan teori hukum yang relevan. Delik
pidana terkait kekerasan Seksual diatur di beberapa peraturan yakni, KUHP, UU
PKDRT, UU TPPO, UU ITE, UU Perlindungan Anak dan UU Pornografi. Namun
undang-undang yang ada belum secara komprehensif mengatur perluasan delik
pidana kekerasan seksual dan pemenuhan hak-hak korban yang tidak termasuk
subyek dari suatu undang-undang, serta permasalahan overregulation juga menjadi
urgensi RUU PKS untuk segera disahkan.
\end{abstract}




\section{PENDAHULUAN}

\subsection{Latar Belakang}

Pengaturan tentang Kejahatan atau kekerasan seksual di Indonesia tersebar diberbagai peraturan perundang-undangan di Indonesia. Tercatat terdapat 7 (tujuh) undangundang, dimulai dari Kitab Undang-Undang Hukum Pidana (KUHP) sampai dengan Undang-Undang Perlindungan Anak mengatur berbagai bentuk dan jenis tindak pidana kekerasan seksual dengan berbagai Modus Operandi. Kekerasan Seksual tidak hanya terjadi secara fisik tapi juga secara verbal dan mental dimana seringkali kekerasan fisik, verbal dan mental mendahului terjadinya kekerasan seksual.

Di dalam Buku Kedua Kitab Undang-Undang Hukum Pidana (KUHP) Indonesia yang masih berlaku saat ini tentang Kejahatan mengatur tentang Kejahatan Terhadap Kesusilaan dalam Bab XIV Dan mengatur dari mulai Pasal 289 sampai Pasal 296 KUHP. KUHP sendiri tidak mengenal istilah pelecehal seksual, namun istilahnya dikenal dengan perbuatan cabul. Perbuatan cabul itu sendiri menurut Ratna, yakni segala macam perbuatan yang dianggap melanggar kesusilaan. Jika berbicara mengenai pelecehan seksual atau sexual harassment diartikan sebagai adanya ketidakinginan atau penolakan pada apapun bentukbentuk perhatian yang bersifat seksual. Sehingga pelecehan seksual itu dapat dijerat dengan pasal pencabulan dalam Pasal 289 sampai Pasal 296 KUHP.

Selain itu, Undang-Undang lain yang mengatur tentang perbuatan cabul atau kejahatan seksual adalah Undang-Undang No. 23 Tahun 2004 tentang Penghapusan Kekerasan dalam Rumah tangga yang mengatur tentang pemerkosaan dalam rumah tangga, Undang-undang No. 21 Tahun 2007 tentang Pemberantasan Tindak Pidana Perdagangan Orang, Undang-Undang No. 44 tahun 2008 tentang Pornografi, Undang-Undang No. 36 Tahun 2009 tentang Kesehatan, Undang-Undang No. 17 Tahun 2016 tentang Perlindungan Anak.

Walaupun banyaknya aturan yang mengatur tentang kejahatan sesksual, masih banyak faktor yang mendasari kurangnya perlindungan hukum terhadap korban kejahatan, salah satunya faktor undang-undang itu sendiri. Penulis mengambil contoh kelemahan terhadap tindak pidana perkosaan dalam KUHP. Rumusan KUHP Indonesia dirasa belum cukup dalam hal mengatur mengenai perkosaan. Seperti perkosaan menggunakan benda cenderung dimasukkan dalam Pasal 351 KUHP tentang Penganiayaan dengan sanksi yang sangat rendah yakni 2 tahun 8 bulan, rumusan KUHP belum mengatur mengenai perkosaan dengan persetujuan (unsur persetujuan korban tetapi diperoleh dengan ancaman), perkosaan sedarah (walaupun diatur secara eksplisit dalam Pasal 81 ayat (3) Peraturan Pemerintah Pengganti UU No.1 Tahun 2016 tentang Perlindungan Anak Jo. Pasal 76 D UU No. 35 Tahun 2014 tentang Perubahan Atas UU No. 23 Tahun 2002 tentang Perlindungan Anak,) dan perkosaan dalam hubungan suami isteri dalam pernikahan (diatur secara eksplisit dalam Pasal 8, Pasal 46 sampai Pasal 48 UU No. 23 Tahun 2004 tentang KDRT).

Pentingnya peraturan perundang-undangan yang mengakomodir permasalahan kekerasan seksual dilatarbelakangi dasar-dasar hukum sebagai berikut:

a) UU No. 39 Tahun 1999 tentang Hak Asasi Manusia.

b) Undang-Undang No. 5 Tahun 1998 tentang Pengesahan Convention against Torture and Other Cruel, Inhuman or Degrading Treatment or Punishment.

c) UU No. 26 Tahun 2000 tentang Pengadilan HAM.

Kedua peraturan perundang-undangan mengakomodir kejahatan terhadap HAM, termasuk kekerasan seksual yang merupakan bentuk dari kejahatan terhadap kemanusiaan.

d) Statuta Roma tahun 1998, Pasal 7 huruf (g) menyebutkan bahwa kejahatan yang termasuk dalam klasifikasi kejahatan kemanusiaan, yakni perkosaan, perbudakan seksual, pemaksaan prostitusi, penghamilan paksa, pemaksaan sterilisasi, atau suatu bentuk kekerasan seksual lain yang cukup berat.

e) Pasal 28 huruf (g) UUD 1945. 
f) UU No. 23 Tahun 2002 tentang Perlindungan Anak.

g) UU No. 35 Tahun 2014 tentang Perubahan Atas UU No. 23 Tahun 2002 tentang Perlindungan Anak.

h) The Convention on the Elimination of All Forms of Discrimination against Women) / CEDAW.

i) UU No. 7 Tahun 1984 tentang Ratifikasi CEDAW.

Berangkat dari dasar hukum di atas, diperkuat pula dengan pernyataan Presiden Joko Widodo bahwa tingginya jumlah kejahatan kekerasan seksual khususnya terhadap anakanak maka kejahatan tersebut dapat dikategorikan sebagai kejahatan luar biasa (extraordinary crime). Berdasarkan uraian di atas, maka penulis akan melakukan penelitian dengan judul Urgensi Pengesahan RUU PKS (Penghapusan Kekerasan Seksual) Dalam Perspektif Hukum Pidana.

\subsection{Rumusan Masalah}

Berdasarkan uraian diatas, maka penelitian ini difokuskan kepada permasalahan sebagai berikut:

1. Bagaimana pengaturan tindak pidana kekerasan seksual di Indonesia?

2. Apa urgensi pengesahan RUU PKS berdasarkan perspektif hukum pidana?

\subsection{Tujuan Penelitian}

Penelitian ini bertujuan untuk mengetahui berbagai macam pengaturan tindak pidana kekerasan seksual yang tersebar di beberapa peraturan perundang-undangan di Indonesia. Mengetahui kelemahan baik dalam peraturan perundangan maupun penegakan hukum terhadap tindak pidana kekerasan seksual dan menganalisis urgensi pengesahan RUU PKS dalam perspektif hukum pidana.

\section{METODE PENELITIAN}

Memuat cara dan langkah dalam kegiatan untuk menjawab permasalahan penelitian. Terdiri dari (tulis dalam bentuk pointers):

\section{Pendekatan}

Penelitian ini menggunakan penelitian hukum normative dengan pendekatan undangundang (statue approach) dan pendekatan analisis (analitycal approach).

\section{Metode Pengumpulan Data}

Pengumpulan data dilakukan dengan mengakses peraturan dan karya ilmiah hukum secara online melalui website JDIH di beberapa instansi pemerintahan dan website beberapa universitas di Indonesia.

\section{Teknik Analisa Data}

Teknik analisis data dengan pendekatan kualitatif yakni dengan menganalisis isu hukum menggunakan bahan kepustakaan, doktrin hukum, teori hukum dan norma hukum yang relevan sehingga menghasilkan argumentasi hukum sebagai jawaban permasalahan.

\section{PEMBAHASAN}

\subsection{Pengaturan Tindak Pidana Kekerasan Seksual Di Indonesia}

\subsubsection{Kejahatan Seksual dalam Kitab Undang-Undang Hukum Pidana.}

Tindak Pidana Kejahatan Kesusilaan secara umum diatur dalam Pasal 281 sampai Pasal 303 Buku Kedua pada Bab XIV tentang Kejahatan Kesusilaan Kitab UndangUndang Hukum Pidana. Perbuatan seksual yang dilakukan oleh laki-laki atau perempuan yang telah kawin (perzinahan) diatur dalam Pasal 284 KUHP; Perkosaan (Pasal 285 KUHP); Melakukan persetubuhan wanita yang tidak berdaya (Pasal 286 KUHP); Bersetubuh dengan anak (perempuan/laki) dibawah umur (Pasal 287 dan 288 KUHP); berbuat cabul (Pasal 289 KUHP); Berbuat cabul dengan orangyang tidak berdaya dan dibawah umur (Pasal 290 KUHP).

Selanjutnya, tindak pidana perbuatan cabul dengan sesama jenis kelamin yang masih dibawa umur (Pasal 292 KUHP); Membujuk untuk berbuat cabut pada orang yang masih 
dibawah umur (Pasal 293 KUHP); berbuat cabul dengan anaknya, tirinya, anak angkatnya, anak dibawah pengawasannya yang belum dewasa (Pasal 294 KUHP ayat (1); Pejabat yang melakukan perbuatan cabul dengan bawahannya atau orang dibawah penjagaannya (Pasal 294 KUHP ayat (1) angka 1); Pengurus, dokter, guru, pegawai, pengawas atau pesuruh penjara, tempat pekerjaan Negara, tempat pendidikan, rumah piatu, rumah sakit atau lembaga sosial terhadap orang yang dimasukan kedalamnya (Pasal 294 ayat (1) angka 2 KUHP.

Tidak hanya bagi pelaku, KUHP juga mengatur pihak ketiga yang membantu dan/atau turut serta dalam Tindak Pidana Kekerasan seksual. Menyebabkan atau memudahkan perbuatan cabul oleh orang lain dan menjadikannya sebagai mata pencarian (Pasal 296 KUHP); Orang yang melakukan perdagangan wanita dan perdagangan anak laki-laki yang belum dewasa (Pasal 297 KUHP); Menarik keuntungan dari perbuatan cabul seorang wanita dan menjadikannya mata pencaharian (Pasal 506 KUHP).

Delik-delik sebagaimana penulis ungkapkan diatas memiliki perbedaan ancaman hukuman yang didasarkan pada pembuktian tiap-tiap unsur-unsur yang ada. Pasal 284 diancam dengan 9 bulan penjara, Pasal 285 diancam dengan 12 tahun penjara, Pasal 286 diancam dengan 9 tahun, Pasal 287 sembilan tahun penjara, Pasal 288 (1) 4 tahun, apabila mengakibatkan luka (2) menjadi 8 tahun dan 12 tahun apabila mengakibatkan kematian. Dalam Pasal 289, 290 dan 294 diancam 7 tahun penjara, Pasal 291 diancam penjara 12 tahun dan 15 tahun apabila kejahatan Pasal 286 sampai 290 mengakibatkan luka dan kematian, Pasal 292, 293 dan 295 (1) diancam 5 tahun penjara, Pasal 295 (2) diancam 4 tahun penjara, Pasal 296 diancam 1 tahun 4 bulan, dan Pasal 297 diancam dengan 6 tahun penjara.

\subsubsection{Kejahatan Seksual diluar Kitab Undang-Undang Hukum Pidana}

Dalam Undang-undang No. 23 Tahun 2004 tentang Penghapusan Kekerasan dalam Rumah Tangga, Tindak pidana kekerasan seksual diatur dalam ketentuan Pasal 8 yang berbunyi "Kekerasan seksual sebagaimana diatur dalam Pasal 5 huruf c meliputi:

a. Pemaksaan hubungan seksual yang dilakukan terhadap orang yang menetap dalam lingkup rumah tangga tersebut;

b. Pemaksaan hubungan seksual terhadap seorang dalam lingkup rumah tangganya dengan orang lain untuk tujuan komersial dan/atau tujuan tertentu.

Sedangkan ancaman bagi pelaku kekerasan seksual sebagaimana disebut diatas adalah 12 tahun penjara (untuk Pasal 8 huruf a) dan 15 tahun penjara (untuk Pasal 8 huruf b). Selanjutnya, ketentuan Pasal 12 Undang-Undang No. 21 Tahun 2007 tentang Pemberantasan Tindak Pidana Perdagangan orang juga mengatur tentang Kekerasan seksual yang terjadi pada korban tindak pidana perdagangan orang. Kekerasan tersebut dibagi kedalam 2 (dua) bentuk, yakni, menggunakan atua memanfaatkan korban tindak pidana perdagangan orang dengan cara melakukan persetubuhan atau perbuatan cabul lain; mempekerjakan korban tindak pidana perdagangan orang untuk meneruskan praktik eksploitasi atau mengambil keuntungan dari hasil tindak pidana perdagangan orang tersebut.

Dalam hal korban tindak pidana kekerasan seksual adalah anak dibawah umur, maka berlaku Undang-Undang Nomor 17 Tahun 2016 tentang perubahan kedua atas UndangUndang No. 23 Tahun 2002 tentang perlindungan anak ("UU Perlindungan Anak") yang mengatur jenis Kekerasan seksual terhadap anak (Lex Specialis). Delik-delik kekerasan seksual dalam UU Perlindungan anak mengatur jenis kekerasan seksual sebagai berikut:

a. Melakukan kekerasan atua ancaman kekerasan memajsa anak melakukan persetubuhan dengan dengann atau orang lain (Pasal 76 D);

b. Melakukan kekerasan atau ancaman kekerasan, memaksa, melakukan tipu muslihat, melakukan serangkaian kebohongan atua membujuk anak untuj melakukan atau membiarkan dilakukannya perbuatan cabul (Pasal $76 \mathrm{E})$; 
c. Menempatkan, membiarkan, melakukan ,menyuruh melakukan, atau turut serta melakukan eksploitasi secara ekonomi dan/atau seksual terhadap anak. (Pasal 76 I)

Pasca disahkannya Peraturan Pemerintah Pengganti Undang-Undang No. 1 Tahun 2016 ("PERPPU") melalui Undang-Undang No. 17 Tahun 2016 tentang Perubahan Kedua UU Perlindungan Anak, ancaman hukuman terhadap pelaku kekerasan seksual terhadap anak mengalami pemberatan, baik dari jenis hukuman maupun lamanya waktu pemidanaan. Misalnya, pelaku kekerasan seksual terhadap anak yang melanggar ketentuan Pasal 76 D dan 76 E diancam pidana paling singkat 5 tahun dan paling lama 15 tahun, dan diperberat sepertiga dari ancaman hukumannya apabila dilakukan oleh keluarga, pengasuh, pendidik dan merupakan pelaku pengulangan tindak pidana kekerasan seksual terhadap anaj (Pasal 81 ayat 2 dan 3), dalam hal kekerasan seksual tersebut menimbulkan akibat lain seperti kematian, luka berat dan gangguan serta akibatakibat lain maka ancaman hukumannya adalah pidana mati, seumur hidup dan penjara paling signkat 10 tahun, paling lama 20 tahun (Pasal 81 ayat 5) dan masih dimungkinkan untuk dikenai pidana tambahan seperti pengumuman identitas pelaku, kebiri kmia dan pemasangan alat pendeteksi elektronik. Selanjutnya, pelaku kekerasan seksual yang melanggar Pasal 76 I diancam pidana paling lama 10 tahun.

Berkembangnnya teknologi informasi dan internet juga memperngaruhi perkembangan Modus Operandi tindak pidana kekerasan seksual melalui media sosial dan internet. Media sosial seolah menjadi ruang baru bagi para pelaku kekerasan seksual dengan berbagai bentuk, misalnya adalah penggunaan kalimat yang tidak senonoh dan bermuatan seksual, pelecehan secara verbal dengan mengirimkan foto atau video yang bermuatan seksual, atau yang paling menyedihkan adalah penggunaan media sosial/internet sebagai ruang untuk mengeksploitasikan korban kekerasan seksual melalui penyebaran foto atau video.

Penyebaran video atau foto tersebut seringkali merupakan bentuk ancaman dari pelaku kekerasan seksual dengan maksud agar korban kekerasan seksual tidak melaporkan kekerasan seksual tersebut. Kekerasan seksual tersebut secara umum sudah diatur didalam Undang-Undang No. 44 Tahun 2004 tentang Pornografi ("UU Pornografi") dan UU No. 16 Tahun 2016 tentang Informasi dan Transaksi Elektronik ("UU ITE").

Ketentuan Pasal 4 ayat (1) huruf b telah mengatur bahwa setiap orang dilarang memproduksi, membuat, memperbanyak, menggandakan, menyebarluaskan, mengimpor, mengekspor, menawarkan, memperjualbelikan, menyewakan atau menyediakan pornografi yang secara ekspilisit memuat kekerasan seksual diancam dengan pidana penjara paling singkat 6 bulan dan paling lama 12 tahun (Pasal 29 UU Pornografi. Begitu juga dengan ketentuan, Pasal 27 ayat (1 UU ITE melarang setiap orang dengan sengaja dan tanpa hak mendistribusikan dan/atau mentransmisikan dan/atau membuat dapat diaksesnya informasi elektronik dan/atau dokumen elektronik yang memiliki muatan yang melanggar kesusilaan diancam dengan pidana penjara paling lama 6 tahun (Pasal 45 ayat 1$)$.

Dalam RKUHP, konsep dan pengertian kekerasan seksual tidak mengalami perubahan yang signifikan, kekerasan seksual tetap dikualifikasikan kedalam dua bentuk, Pencabulan dan Pemerkosaan yang membedakan hanya ada pada perluasaan unsur delik dalam Pemerkosaan dan Pencabulan. RUU PKS membagi kekerasan seksual kedalam 9 jenis meliputi: a) Pelecehan seksual (Pasal 12); b) Eksploitasi seksual (Pasal 13); c) Pemaksaan kontrasepsi (Pasal 14); d) Pemaksaan aborsi (Pasal 15); e) Perkosaan (Pasal 16 e); f) Pemaksaan perkawinan (Pasal 17); g) Pemaksaan pelacuran (Pasal 18); h) Perbudakan seksual (Pasal 19); dan/atau; i) Penyiksaan seksual (Pasal 20). RUU PKS bagi sebagian kalangan dianggap sebagai Undang-Undang yang komplit dan merupakan solusi serta harapan bagi para korban kekerasan seksual.

\subsection{Urgensi Pengesahan Ruu Pks Berdasarkan Perspektif Hukum Pidana}




\subsubsection{Prinsip Hukum Pidana dan Pemidanaan}

Prinsip dari hukum pidana, yakni adanya kerugian berbentuk penderitaan yang negara sengaja berikan kepada seseorang yang terbukti melanggar hukum. Pendidikan secara moral dan mental terhadap seseorang yang terbukti melanggar hukum, tujuan itu merupakan hakikat dari pemidanaan. Hukum Pidana memiliki tujuan untuk melindungi kepentingan personal, Hak Asasi Manusia dan kepentingan umum yang seyogyanya selaras dengan ideologi Pancasila sehingga memberikan keadilan untuk seluruh lapisan masyarakat dan Warga Negara Indonesia. Tujuan pemidanaan memiliki 4 (empat) pokok hakikat, yakni:

a. Pencegahan umum dan khusus.

b. Perlindungan masyarakat.

c. Memelihara solidaritas masyarakat.

d. Pengimbalan/pengimbangan.

\subsubsection{Teori Pemidanaan}

Teori pemidanaan dibagi menjadi 3 (tiga) golongan, yaitu teori absolut (pembalasan), teori relative (teori tujuan), dan teori gabungan. Teori pertama tentang Teori Absolut, menurut Andi Hamzah, intinya teori absolut/pembalasan itu tidak memikirkan manfaat penjatuhan pidana karena kejahatan itu sendiri mengandung unsur-unsur penjatuhan pidana. Dapat disimpulkan bahwa teori pembalasan ini mengesampingkan hak asasi manusia dalam hal ini hak asasi dari pelaku kejahatan.

Teori Kedua tentang teori relative/tujuan. Sebenarnya teori ini juga disebut teori kemanfaatan/teori utilitarian. Menurut Koeswadji, intinya teori relative ini bertujuan menjaga ketertiban umum, merestorasi kerugian korban/masyarakat akibat kejahatan itu, merestorasi pelaku kejahatan dan sebagai upaya preventif kejahatan. Teori Ketiga tentang teori gabungan bertujuan bahwa pidana itu selain untuk membalas kejahatan pelaku juga sebagai alat untuk melindungi ketertiban umum serta masyarakat luas. Masih dalam lingkup teori gabungan, terdapat suatu teori yakni teori integrative yang menitikberatkan pada hal-hal berikut:

a. pembalasan tapi tidak boleh melampaui batas apa yang perlu dan sudah cukup untuk menjaga ketertiban umum.

b. Penertiban umum ditegakan namun tidak boleh lebih berat dari penderitaan pelaku kejahatan. Jadi beratnya pemidanaan harus seimbang dengan beratnya/ tingkat keparahan tindak pidana itu.

c. Perlu ada keseimbangan antara 2 (dua) point di atas.

Berdasarkan uraian di atas, hubungan antara hukum pidana dan pemidanaan tentunya masih berfokus utama pada pelaku tindak pidana dibandingakan korban tindak pidana. Penulis sepakat terhadap pemidanaan dengan teori gabungan, bahwa kejahatan pelaku harus tetap dibalas seimbang atau setara dengan beratnya kejahatan yang dilakukan, namun harus tetap memperhatikan hak asasi manusia dari pelaku kejahatan dengan pemidanaan yang tidak melampaui batasannya dengan kata lain pemidanaan harus tetap proporsional.

Selain itu perlindungan masyarakat atau ketertiban umum menurut hemat penulis dapat diartikan sebagai perlindungan individual, warga negara Indonesia, dan korban tindak pidana maupun tindak pidana kekerasan seksual yang perlu perhatian khusus oleh perumus peraturan perundang-undangan, aparat penegak hukum dan seluruh masyarakat Indonesia. Namun bagaimana perspektif hukum pidana terhadap perlindungan korban tindak pidana itu sendiri, dalam penelitian ini akan membahas perspektif hukum pidana terhadap korban tindak pidana kekerasan seksual.

\subsection{Perlindungan Hak-Hak Korban Tindak Pidana Kekerasan Seksual}

Perhatian terhadap perlindungan hak korban tindak pidana dan khususnya korban tindak pidana kekerasan seksual seringkali luput dalam persoalan kriminalisasi. Berbagai macam peraturan perundang-undangan mengatur deliknya sendiri tentang persoalan 
kekerasan seksual, namun sangat sedikit yang menjelaskan pengertian korban dan perlindungan atas hak-hak korban. Bahkan sekalipun dalam UU No. 23 Tahun 2002 tentang Perlindungan Anak dan perubahannya dalam UU No. 35 Tahun 2014 belum mengatur definisi korban maupun definisi anak korban. Pendefinisian korban juga belum dijelaskan dalam KUHP maupun KUHAP, dalam KUHAP korban hanya dinilai sebagai saksi.

Persoalan mengenai definisi korban dalam tindak pidana kekerasan seksual serta perlindungan hak-hak korban perlu diatur secara khusus dalam peraturan perundangundangan sebagai pembaharuan hukum pidana. Hal ini dikarenakan kekerasan seksual merupakan kejahatan yang pasti melibatkan korban, berdampak secara fisik, sosial dan mental. Korban adalah bagian dari warga negara sehinga memiliki hak-hak khusus yang wajib dipenuhi negara. Adapun bila berbicara mengenai pemenuhan dan perlindungan hak korban kekerasan seksual telah diatur di beberapa peraturan perundang-undangan seperti:

a. secara normatif dalam UU Perlindungan Anak yang menyebutkan bahwa pelaksanaannya merupakan kewajiban pemerintah dan pemerintah daerah tanpa disertai peraturan pelaksanaannya.

b. UU Perlindungan Saksi dan Korban juga memberikan bantuan psikologis, medis, rehabilitasi dan psikoseksual.

c. UU Penghapusan Kekerasan dalam Rumah Tangga pun mengatur tentang perlindungan hak-hak korban.

d. UU Tindak Pidana Perdagangan Orang yang mengakomodir hak korban kekerasan seksual berupa rehabilitasi social, kesehatan, pemulangan dan reintegrasi social melalui rumah perlindungan sosial atau pusat trauma.

Dengan tersebarnya pengaturan pemenuhan hak korban yang berbeda-beda di berbagai peraturan perundang-undangan mengakibatkan perlindungan dan pemenuhan hak korban kekerasan seksual tidak terfokus dan terkoordinasi dengan baik. Contoh tidak terkoordinasinya pemenuhan hak korban secara komprehensif, yakni :

a. Implementasi UU PKDRT oleh Kementerian Pemberdayaan Perempuan dan Perlindungan Anak telah melahirkan Pusat Pelayanan Terpadu Pemberdayaan Perempuan dan Anak (P2TP2A) justru disalahgunakan oleh Oknum Ketua P2TP2A Lampung yang melakukan pemerkosaan terhadap korban yang dititipkan, kemudian korban dijual menjadi pekerja seks.

b. Perlindungan korban kekerasan seksual masih menjadi tanggungan LPSK berdasarkan UU LPSK. Namun LPSK masih terpusat di Jabodetabek sehingga korban diluar domisili itu belum mampu dijangkau oleh LPSK, terlebih LPSK menangani seluruh korban tindak pidana, tidak hanya kekerasan seksual saja.

Pengaturan Hak Layanan Korban dalam berbagai regulasi, menunjukkan bahwa setiap regulasi yang mengkriminalisasi perbuatan kekerasan seksual hanya mengakomodir hak-hak korban berdasarkan delik yang diatur dalam suatu peraturan perundang-undangan. Contohnya, UU Perlindungan Anak dan UU Sistem Peradilan Pidana Anak hanya akan mengakomodir pelayanan terhadap anak. UU PKDRT hanya melayani hak korban kekerasan dalam rumah tangga. UU Tindak Pidana Perdagangan Orang hanya melayanain hak korban tindak pidana perdagangan orang. Sehingga korban kekerasan seksual yang terkena tindak pidana kekerasan seksual namun belum diatur dalam suatu peraturan perundang-undangan khusus, tidak akan mendapatkan pelayanan tehadap pemenuhan dan perlindungan hak-haknya. Contohnya:

a. Korban perkosaan yang dilakukan orang asing, maka yang akan berlaku ketentuannya adalah KUHP. Namun KUHP tidak mengakomodir perlindungan terhadap hak korban.

b. Kasus Baiq Nuril, korban pelecehan seksual yang malah menjadi terdakwa dan terjerat Pasal 27 ayat 1 jo. Pasal 45 ayat 1 UU ITE. Walaupun memang tidak dapat dicampuradukkan antara cyber crime dengan tindak pidana kekerasan seksual. Namun Pasal 27 ayat 1 UU ITE berhubungan dengan Pasal 310 KUHP tentang 
Penghinaan. Merujuk pada pendapat R.Soesilo bahwa perbuatan penghinaan/pencemaran nama baik berdasarkan Pasal 310 KUHP dapat dikecualikan/tidak dapat dihukum apabila dilakukan untuk membela kepentingan umum atau terpaksa untuk membela diri. Dalam kasus ini, Baiq Nuril sudah melaporkan Pelaku ke Polda NTB dengan tuduhan Pasal 291 ayat (2) Ke-1 KUHP tentang Perbuatan Cabul dalam sebuah relasi kerja, namun tidak dapat terpenuhi karena kurangnya bukti. KUHP sendiri belum mengakomodir perlindungan terhadap hak korban, sehingga hal ini menunjukkan bahwa Korban Tindak Pidana Kekerasan Seksual seperti Baiq Nuril belum terakomodir perlindungan dan pemenuhan haknya dalam peraturan perundang-undangan manapun, dikarenakan belum adanya peraturan perundang-undangan yang mengatur secara khusus mengenai tindak pidana kekerasan seksual.

c. Kasus Gilang Aprilian Nugraha Pratama (Gilang Bungkus) yang menjadi tersangka pelaku fetish kain jarik dijerat Pasal 27 ayat (4) jo. Pasal 45 ayat (4) UU ITE dan Pasal 335 KUHP. Namun lagi-lagi dalam hal ini, perlindungan terhadap hak korban belum terpenuhi dikarenakan delik yang dituduhkan pada pelaku berdasarkan UU ITE dan KUHP,yang mana kedua UU tersebut belum mengatur mengenai pemenuhan terhadap perlindungan hak-hak korban kekerasan seksual.

\subsection{Perbandingan ketentuan mengenai Tindak Pidana Kekerasan Seksual di KUHP, RUU KUHP DAN RUU PKS}

RUU PKS lebih komprehensif dalam perumusan delik, pendefinisian korban dan juga sebagai suatu tindak pidana khusus merujuk pada asas lex specialis derogate legi generalis, sudah seharusnya RUU PKS ditindaklanjuti dalam prolegnas, melihat RUU KUHP sendiri pun belum mengatur secara komprehensif mengenai tindak pidana kekerasan seksual, yang mana berdasarkan statistic criminal dan perkemangan kehidupan manusia dan teknologi yang sangat cepat, maka timbulah berbagai macam jenis kejahatan modus baru, khususnya mengenai fenomena kekerasan seksual ini yang mengalami perluasan kejahatan sehingga seyogyanya dapat dirumuskan secara khusus dan komprehensif.

Berangkat dari permasalahan-permasalahan yang telah penulis ungkapkan diatas, beberapa hal yang menjadi urgensi disahkannya RUU PKS adalah sebagai berikut:

a. Pertama, adanya kekosongan hukum dan/atau ketidakpastian hukum terkait pengaturan Tindak Pidana Kekerasan Seksual melalui Undang-Undang yang ada. Hal ini disebabkan undang-undang yang ada saat ini belum secara komprehensif mengatur tentang berbagai bentuk-bentuk perluasan kejahatan kekerasan seksual yang terjadi dalam masyarakat, maka daripada itu,diperlukan adanya suatu aturan yang secara khusus mengatur tentang Pencegahan, Perlindungan, Penegakan dan pemenuhan hak-hak korban tindak pidana kekerasan seksual. Dalam aspek perlindungan misalnya, Undang-Undang saat ini belum dapat memberikan jaminan perlindungan yang memadai, bahkan dalam beberapa kasus seperti baiq nuril, korban kekerasan seksual justru terpaksa menjadi korban kekerasan seksual sekaligus korban kriminalisasi dan diskriminasi. Kemudian kasus Gilang Bungkus, yang menggunakan modus baru dengan penggunaan kain jarik kepada korban yang bahkan korban hamper semuanya laki-laki, walaupun dilakukan dengan cara jarak jauh/online, namun hal-hal ini merupakan bentuk nyata perluasan dari kejahatan kekerasan seksual seiring dengan perkembangan kehidupan manusia dan teknologi.

b. Kedua, perlindungan hak korban itu berdasarkan asas legalitas terhadap suatu delik yang terdapat dalam Undang-Undang. Artinya jika korbannya anak maka dilindungi oleh UU Perlindungan Anak, jika korbannya suami-isteri dalam perkawinan maka dilindungi UU PKDRT, dan jika korbannya eksploitasi berdasarkan UU TPPO maka korban dilindungi oleh UU TPPO. Sehingga korban yang tidak termasuk dalam subyek di berbagai macam UU yang mengatur tentang kekerasan seksual, tidak akan 
mendapatkan perlindungan dan pemenuhan hak-hak atas korban, dikarenakan belum ada UU yang mengatur secara khusus.

c. Ketiga, terlalu banyak regulasi (overregulation) yang menyebabkan pemidanaan dan perlindungan terhadap hak korban tidak tersistematis dan terkoordinasi dengan baik. Apabila dalam kasus, bukti-bukti kekerasan seksual itu tidak dapat dibuktikan, atau terdapat keragu-raguan hakim maka berdasarkan asas In Dubio Pro Reo, terdakwa dapat diberikan hal yang menguntungkan yaitu dibebaskan dari dakwaan. Kemudian dari perspektif pemenuhan dan perlindungan hukum terhadap korban, berdasarkan kasus yang telah diuraikan di atas, Lembaga-lembaga yang menaungi perlindungan saksi dan korban (LPSK) masih terpusat sehingga tidak dapat mencapai korbankorban diluar domisili jabodetabek, kemudian kasus Lembaga P2TP2A Lampung menunjukkan bahwa Lembaga yang berkewajiban untuk melindungi korban sekalipun tidak menjadi tempat pelayanan dan perlindungan yang aman akibat oknum-oknum tertentu. Kemudian tidak adanya peraturan pelaksana dari UU Perlindungan Anak, sebagai aturan turunan/pelaksanaan dari UU tersebut, menjadi hambatan dalam penyelenggaraan perlindungan anak. Sehingga, berdasarkan hemat penulis, RUU PKS perlu segera disahkan dengan beberapa saran dari masyarakat serta didukung peraturan pelaksana yang jelas dan komprehensif, juga kerjasama dari seluruh pihak, baik legislator, Aparat Penegak Hukum dan seluruh lapisan masyarakat.

\section{KESIMPULAN}

Berdasarkan pembahasan yang telah penulis paparkan sebelumnya, dapat kesimpulan tentang pengaturan tindak pidana kekerasan seksual dan urgensi pengesahan RUU PKS dalam perspektif hukum pidana, yaitu:

1. Tindak Pidana Kekerasan seksual telah diatur dalam KUHP maupun Undang-Undang lain seperti Undang-undang Penghapusan Kekerasan dalam Rumah Tangga, Undang-Undang tentang Pemberantasan Tindak Pidana Perdagangan Orang, Undang-undang Perlindungan Anak, Undang-Undang Tentang Pornografi dan Undang-Undang tentang Informasi dan Transaksi Elektronik. Diaturnya Tindak Pidana Kekerasan seksual dalam Undang-Undang tersebut diatas menciptakan pengaturan delik dan ancaman hukuman dari pelanggaran Tindak Pidana Kekerasan Seksual menjadi beragam. Kendati demikian, Undang-Undang yang ada saat ini dirasa belum cukup untuk mengakomodasi perluasan bentuk Tindak Pidana Kekerasan Seksual dari sebelum, saat dan sesudah terjadinya kekerasan seksual serta belum memberikan jaminan pemenuhan serta perlindungan hak-hak korban.

2. Urgensi pengesahan RUU PKS berdasarkan perspektif pidana didasarkan pada beberapa argumentasi. Pertama, adanya kekosongan hukum dan/atau ketidakpastian hukum terkait pengaturan Tindak Pidana Kekerasan Seksual melalui Undang-Undang yang ada. Hal ini disebabkan undang-undang yang ada saat ini belum secara komprehensif mengatur tentang berbagai bentuk-bentuk perluasan kejahatan kekerasan seksual seiring dengan perkembangan kehidupan manusia dan teknologi yang pesat.

Kedua, perlindungan hak korban itu berdasarkan asas legalitas terhadap suatu delik yang terdapat dalam Undang-Undang. Artinya korban yang tidak termasuk dalam subyek di berbagai macam UU yang mengatur tentang kekerasan seksual, tidak akan mendapatkan perlindungan dan pemenuhan hak-hak atas korban, dikarenakan belum ada UU yang mengatur secara khusus. Ketiga, terlalu banyak regulasi (overregulation) yang menyebabkan pemidanaan dan perlindungan terhadap hak korban tidak tersistematis dan terkoordinasi dengan baik. Sehingga, berdasarkan hemat penulis, RUU PKS perlu segera disahkan dengan beberapa saran dari masyarakat serta didukung peraturan pelaksana yang jelas dan komprehensif, juga kerjasama dari seluruh pihak, baik legislator, Aparat Penegak Hukum dan seluruh lapisan masyarakat. 


\section{Saran}

Dibalik berbagai tujuan dan urgensi yang penulis telah ungkapkan diatas, harus diakui bahwa RUU PKS bukanlah RUU yang sempurna. Terdapat beberapa hal yang yang harus diperhatikan dan menjadi masukan bagi Pembentuk Undang-Undang dalam proses perumusan dan pembahasan RUU PKS. Pertama, terkait dengan sifat RUU PKS, apakah merupakan Undang-Undang Administratif yang memuat sanksi pidana atau Undang-Undang Pidana Khusus. Hal ini penting karena akan sangat berkaitan dengan implementasi dan penerapan RUU PKS saat ketika sudah disahkan dan berlaku. Terkait dengan hal itu, terdapat beberapa perbedaan pendapat, Prof Edward Omar Sharif menyampaikan bahwa upaya penghapusan kekerasan seksual jangan dibawa keranah hukum pidana administrative, namun harus sebagai UU Pidana. Sedangkan Chairul Huda dalam RDPU di DPR mengemukakan bahwa RUU PKS sebaiknya fokus kepada aspek pencegahan yang berarti RUU PKS akan menjadi UndangUndang yang bersifat administratif. Terlepas dari pendapat tersebut, penulis memandang bahwa semangat Penghapusan Kekerasan Seksual harus dibawa ke aspek Hukum Pidana (Khusus) karena kekerasan seksual merupakan perbuatan tercela (Mala Per se).

Kedua, terkait dengan perumusan tiap-tiap delik, hal-hal yang harus diperhatikan adalah kerangka hukum mengenai Kekerasan Seksual yang sampai saat ini masih tersebar diberbagai Peraturan Perundang-Undangan lain, Kebijakan penal dan non-penal serta singkronisasi RUU PKS dengan Undang-Undang yang ada dan berlaku saat ini. Unsur-unsur delik yang diatur dalam delik-delik dalam RUU PKS tidak begitu jelas tergambar, seperti unsur subjektif, unsur objektifnya, unsur straf modusnya, sampai unsur akibat harus ditata secara baik sesuai dengan asas-asas dan teori pembentukan hukum pidana. Selanjutnya terkait dengan Pengaturan Delik dalam RUU PKS yang bersinggungah dengan delik yang telah ada dalam Undang-Undang lain. Misalkan delik Perkosaan dan Pemaksaan aborsi, dalam KUHP dan RKUHP. Bagi delik pemerkosaan menurut hemat penulis berdasarkan uraian di atas, terdapat beberapa kekurangan yang sekiranya dapat dipertimbangkan untuk dimasukkan dalam RKUHP. Selanjutnya delik Aborsi sudah diatur didalam Pasal 346-349 KUHP, apabila ingin diatur kembali dalam RUU PKS, perlu adanya kualifikasi subjek korban pemaksaan aborsi tersebut, yakni, korban pemaksaan aborsi yang juga merupakan korban tindak pidana kekerasan seksual. Dalam hal korban pemaksanaan aborsi bukan merupakan korban tindak pidana kekerasan seksual maka, akan lebih tepat jika delik Pemaksaan Aborsi dalam RUU PKS dimasukan kedalam KUHP atau RKUHP sebagai kualifisir dari delik umumnya.

Delik Pemaksaan Perkawinan dalam RUU PKS perlu memperhatikan dan menyesuaikan sifat masyarakat yang multi-etnis dan heterogen termasuk didalamnya Perkawinan Adat yang dalam praktiknya juga terdapat kewajiban melaksanakan pemenuhan nilai-nilai adat istiadat yang sedikit banyak juga bersifat "memaksa" pelaku perkawinan. Dalam keadaan yang demikian, apakah hal itu dapat dikualifikasi sebagai Tindak Pidana Kekerasan seksual sebagaimana dimaksud dalam RUU PKS? Tentu diperlukan adanya pengecualian terhadap hal tersebut, dan menjadi kewajiban Pembentuk Undang-undang agar pelaksanaan aturan hukum tidak bertentangan atau mendegradasi nilai-nilai yang hidup dalam masyarakat.

Ketiga, terkait dengan Perumusan subjek dan sanksi pidana dalam RUU PKS. Perumusan subjek dan sanksi Tindak Pidana Kekerasan Seksual secara teori harus ditunjang oleh sub-sub system lainnya, yakni sub sistem pedoman dan asas pemidanaan yang ada didalam aturan umum (KUHP) atau aturan khusus dalam Undang-Undang Khusus yang bersangkutan. Hal ini demikian dianggap penting guan terciptanya harmoniassi dan ksatuan sistem dalam hukum pidana, serta menghindari timbulnya masalah penerapan hukum pada saat diterapkan. Misalkan terkait dengan subjek, perlu diatur lebih rinci dan karena hal ini akan terkait dengan subjek kekerasan seksual yang tersebar di peraturan perundan-undangan lain Seperti KUHP, UU Perlindungan Anak, UU Pemberantasan Tindak Pidana Perdagangan Orang, UU Pornografi dan UU ITE.

Mengenai pola pemidanaan seperti maksimum khusus, minimum umum dan minimum khusus. Walaupun kekerasan seksual dianggap sebagai kejahatan Ancaman sanksi dalam RUU 
PKS dinilai sangat berat atau yang biasa disebut sebagai overciriminalization atau overpenalization. Padahal seharusnya, perlu adanya tingkatan ancaman hukum yang didasarkan pada hal ini tentu tidak sejalan dengan asas ultimum remedium dan orientasi hukum pidana progresif.

Dalam hal pemidanaan kasus tindak pidana kekerasan seksual maupun tindak pidana khusus lainnya, perumus regulasi perlu merumuskan tingkat keseriusan kejahatan tindak pidana kekerasan seksual. Hal ini untuk mencegah terjadinya overcriminilazation. Serta aparat penegak hukum dalam porsinya perlu mempertimbangkan faktor-faktor tertentu sehingga pemidanaan terhadap pelaku menjadi proporsional.

Untuk menghindari overcriminalization juga dapat dilakukan dengan jenis sanksi pidana baru masih merujuk pada tulisan Mirco Bargaric, yakni:

1) Sanksi ketenagakerjaan yakni pelaku dilarang melakukan suatu pekerjaan baik yang dibayar maupun tidak dibayar dalam periode yang ditentukan oleh hakim.

2) Sanksi Pendidikan, yakni dengan memusnahkan atau menghapuskan prestasi pendidikan seseorang/mencabut gelar pendidikan, atau menangguhkannya dalam periode tertentu.

Berangkat dari jenis sanksi pidana baru tersebut, menurut hemat penulis dapat dijadikan alternatif pemidanaan agar tidak menyebabkan overcriminalization, namun perlu dilihat dan dipertimbangkan juga hubungan antara sanksi pidana baru tersebut dengan tingkat kerusakan dan tingkat keseriusan akibat dari tindak pidana kekerasan seksual yang dilakukan oleh pelaku. Selanjutnya perlu penelitian yang lebih mendalam atas kritik dan saran yang telah dikemukakan oleh penulis. Merujuk pada uraian di atas, dapat dipertimbangkan sebagai saran dan kritik terhadap perumusan dan keurgensian pengesahan RUU PKS.

\section{DAFTAR PUSTAKA}

\section{Undang-Undang}

Undang-Undang Republik Indonesia Nomor. 23 Tahun 2004 tentang Penghapusan Kekerasan dalam Rumah tangga.

Undang-Undang Republik Indonesia Nomor. 21 Tahun 2007 tentang Pemberantasan Tindak Pidana Perdagangan Orang.

Undang-Undang Republik Indonesia Nomor. 44 tahun 2008 tentang Pornorgrafi.

Undang-Undang Republik Indonesia Nomor. 23 Tahun 2002 tentang Perlindungan Anak.

Undang-Undang Republik Indonesia Nomor. 35 Tahun 2014 tentang Perubahan Atas UU Nomor. 23 Tahun 2002 tentang Perlindungan Anak.

Undang-Undang Republik Indonesia Nomor. 16 Tahun 2016 tentang Informasi dan Transaksi Elektronik.

Undang-Undang Republik Indonesia Nomor. 17 Tahun 2016 tentang Penetapan PERPPU Nomor. 1 Tahun 2016 tentang Perubahan Kedua Atas Undang-Undang Republik Indonesia Nomor. 23 Tahun 2002 tentang Perlindungan Anak.

Rancangan Undang-Undang Kitab Undang-Undang Hukum Pidana September 2019

Rancangan Undang-Undang Penghapusan Kekerasan Seksual 1 Februari 2017

\section{Buku}

Badan Pusat Statistik. (2019). Statistik Kriminal Tahun 2019. Jakarta : Badan Pusat Statistik

Bagaric, Mirco. (2001). Punishment and Sentencing: A Rational Approach. London : Cavendish: Publishing Limited.

Gerstenfeld, Phyllis B. (2008). Crime \& Punishment In The United States. New Jersey : Salem Press, Inc.

Hamzah, Andi. (1993). Sistem Pidana dan Pemidanaan Indonesia. Jakarta: Pradnya Paramita.

Irianto, Sulistyowati. (2013). Perempuan dan Anak Korban Kejahatan Seksual. Jakarta: PT. Raja Grafindo Persada.

Hatta, Muhammad. (2019). Kejahatan Luar Biasa (Extraordinary Crime). Lhokseumawe: Unimal Press. 
Koeswadji,(1995). Perkembangan Macam-macam Pidana Dalam Rangka Pembangunan Hukum Pidana, Cetakan I. Bandung: Citra Aditya Bhakti.

Matravers, Matt. (2000). Justice And Punishment; The Rationale Of Coercion. Oxford: Oxford University Press.

Muladi dan Barda Nawawi Arief, (1992). Teori dan Kebijakan Pidana,. Bandung:Alumni,

Nurthahyo, Lidwina Inge. (2015). Hukum Perlindungan Perempuan dan Anak. The Asia Fondation

Rahmawati, Madina dan Supriyadi Widodo Eddyono, (2017). Menuju Penguatan Hak Korban Dalam RUU Penghapusan Kekerasan Seksual.. Jakarta : ICJR.

Muzakkir. (2010). Mekanisme Penanganan Hukum Tindak Pidana Kesusilaan. Jakarta: BPHN

Soesilo, R. (1996). Kitab Undang-Undang Hukum Pidana (KUHP). Bogor: Politeia

\section{Jurnal}

Agung Ngurah Galang Widura Pandji dan Gde Made Swardhana, Makalah "Relevenasi Pidana Mati Dalam Tindak Pidana Kejahatan Luar Biasa (Extraordinary Crime) Dalam Perspektif Pembaharuan Hukum Pidana Indonesia", diakses dari https://ojs.unud.ac.id/index.php/kerthawicara/article/view/43583/26574

Candra, Septa. (2013). "Perumusan Ketentuan Pidana dalam Peraturan Perundang-Undangan di Indonesia”. Jurnal Hukum PRIORIS, Vol. 3 No. 3

Wardani, Kusuma Dewi. (September-Desember 2018). "Perbandingan Pengaturan Tindak Pidana Perkosaan menurut Kitab Undang-Undangn Hukum Pidana (KUHP) Indonesia dan Malaysia Penal Code". Recidive Volume 7 No.3

Laporan Singkat Komisi VIII DPR RI, RDPU Panja Komisi VII DPR RI mengenai RUU tentang Penghapusan Kekerasan Seksual, 2018

Usman. (2011) “Analisis Perkembangan Teori Hukum Pidana”,Jurnal Ilmu Hukum Jambi.

\section{Media Online}

A Hernawan, Dua dari 9 tindak pidana di RUU PKS Bakal masuk RUU KUHP, diakses dari https://www.gatra.com/detail/news/486773/hukum/dua-dari-9-tindak-pidana-di-ruu-pksbakal-masuk-ruu-kuhp.

Dhimas Budi Pratama, Polda NTB Hentikan Penyelidikan Laporan Baiq Nuril, diakses dari https://www.antaranews.com/berita/789039/polda-ntb-hentikan-penyelidikan-laporanbaiq-nuril pada tanggal 11 Agustus 2020 pukul 11.51 WIB

Hernawan, A, Dua dari 9 tindak pidana di RUU PKS Bakal masuk RUU KUHP, diakses dari https://www.gatra.com/detail/news/486773/hukum/dua-dari-9-tindak-pidana-di-ruu-pksbakal-masuk-ruu-kuhp.

M Rosseno Aji, Polisi Jerat Gilang Bungkus Fetish Kain Jarik dengan UU ITE, diakses dari https://nasional.tempo.co/read/1373833/polisi-jerat-gilang-bungkus-fetish-kain-jarikdengan-uu-ite/full\&view=ok

Ratna Batara Munti, Kekerasan Seksual :Mitos dan Realitasdikutip dari Diana Kusumasari, Jerat Hukum dan Pembuktian Pelecehan Seksual, diakses dari https://m.hukumonline.com/klinik/detail/ulasan/c13746/pelecehan-seks/

Setyo Puji, Ngakunya Perlindungan Anak Ternyata Biadab, diakses dari https://regional.kompas.com/read/2020/07/05/16000071/-ngakunya-perlindungan-anakternyata-biadab-?page=all\#page2 